\title{
A pandemia que nos mostra quem somos?
}

\author{
Monica Daltro' 1 (1) \\ João de Deus Barreto Segundo² (1)
}

1Autora para correspondência. Escola Bahiana de Medicina e Saúde Pública (Salvador). Bahia, Brasil. monicadaltro@bahiana.edu.br
2João de Deus Barreto Segundo. Escola Bahiana de Medicina e Saúde Pública (Salvador), Universidade Federal da Bahia (Salvador). Bahia, Brasil. jao.barreto@gmail.com

Freud (1974), um dos mais importantes cientistas do século XIX, afirmava que a civilização se organiza a partir da renúncia à satisfação pulsional e do permanente exercício para repressão das pulsões. Para ele, o trabalho da civilização engendra a defesa desta, contra o indivíduo, que reivindica sua felicidade e tenta, a todo custo, evitar suas fontes de sofrimento, entre elas: a incontrolável força da natureza, a deterioração e decadência do próprio corpo, e o sofrimento resultante das relações entre os humanos (1996). Ou seja, as demandas próprias da vida civilizada são promotoras de um mal-estar que atravessa o indivíduo na humanidade, pois se contrapõe aos anseios dos indivíduos, gerando desconfortos, sintomas, formas de adoecer em um permanente tensionamento entre a busca da felicidade e o desenvolvimento da civilização. Dessa forma, os processos de subjetivação abarcariam o tensionamento entre o desejo e a insatisfação, implicando um preço a ser pago pelos sujeitos humanos em troca de uma existência coletiva. Em nome da alteridade, que reconhece e observa a importância do outro, o humano contudo se dispõe a abrir mão de uma parcela de sua liberdade e de seus desejos.
Byung-Chul Han(2018) - filosofo coreano que constrói uma leitura do mundo contemporâneo como uma "sociedade do cansaço" - ao analisar os processos de subjetivação do século $X X$, afirma que gradativamente o tempo em que o outro existia vai se extinguindo e o narcisismo se inflando. Isso porque, ao longo da história, o capitalismo atualizado hoje na forma de neoliberalismo, engendrou uma maciça desigualdade social de ordem global. A sociedade global, em si, passa a vincular-se a uma lei de mercado estruturada pela concentração de capitais entre aqueles que muito já os têm, desumanizando o sujeito, alimentando as precariedades sociais, relegando ao segundo plano coisas como solidariedade, civismo, compaixão e promovendo uma cultura isolacionista de medo e terror. Cultivando elementos destrutivos, esse sistema econômico testemunha a irrupção do singular através, dentre outros elementos da violência. Enquanto alguns poucos podem viver na ilha do bem-estar, um exército de excluídos vai se constituindo rodeados por vedações de fronteiras, literais e metafóricas, materiais e subjetivas. 
Para Han (2017), o século XX, foi a época imunológica, na qual se estabeleceram as nítidas diferenças entre o dentro e o fora, o próprio e o estranho, o homem e a mulher, polarizações e raciocínios binários que marcaram a organização social da época, guerras francas, guerras frias, dos gêneros fixos, da AIDS, da exploração do trabalho, das disciplinas e obediência das perspectivas promotoras de subjetividades circulantes entre $o$ negativo e o positivo, entre o certo e o errado, entre o bem e o mal, entre a resistência e a passividade.

Viveríamos segundo ele (Han, 2018a) o período pósimunológico, no qual cujo regime neoliberal é marcado pelo empobrecimento da negatividade, pela exclusão da dialética e da alteridade. O regime reforça uma lógica positiva que afirma a todo tempo uma liberdade singular fora do social e engendrada numa certa narrativa de meritocracia, na capacidade de consumo e trabalho:

Quem fracassa na sociedade neoliberal de desempenho, em vez de questionar a sociedade ou o sistema, considera a si mesmo como responsável e se envergonha por isso. Aí está a inteligência peculiar do regime neoliberal: não permite que emerja qualquer resistência ao sistema. No regime de exploração imposta por outro, ao contrário, é possível que os explorados se solidarizem e juntos se ergam contra o explorador. Essa é a lógica que fundamenta a ideia marxista da 'ditadura do proletariado', que pressupõe, porém, relações repressivas de dominação. Já no regime neoliberal de autoexploração, a agressão é dirigida contra nós mesmo. Ela não transforma os explorados em revolucionários, mas sim em depressivos. (Han, 2018a,16)

Esses depressivos se multiplicam e são acompanhados pelos portadores de transtornos de ansiedade, de atenção, de concentração, por um exército de sujeitos do desempenho que fracassaram em sustentar permanentemente o Yes, we can. Nesse cenário, o desempenho assume o lugar mandatário nas formas de existir na sociedade, uma sociedade de desiguais, cada vez menos amparada pelo Estado. Um Estadoneoliberal que desvaloriza o lugar das pessoas na economia. Agudiza-se assim a necessidade de excessos que se materializam na hiperinformação, na autocoerção, na autoexploração, onde cada sujeito torna-se, diz Han (2018) explorador de si mesmo. Emerge assim uma sociedade que adoece e se medica para produzir consumidores, precarizados no desejos, imaginariamente satisfeitos ou insatisfeitos como a dimensão do TER.
O tensionamento apontado por Freud assume assim um polo, seu equilíbrio desfeito. Os governos, que são feitos de pessoas - e, tradicionalmente, de elites, e, normalmente, elites econômicas -, se apropriam da fragilidade dos sujeitos no tensionamento entre desejos e liberdades individuais a partir de uma promessa de gozo infinito que nunca se cumpre, exceto para as próprias elites. A promessa diz que o indivíduo no liberalismo pode ou poderá um dia tudo o que sonha, tudo o que deseja, suas vontades plenamente satisfeitas. O ápice disto se daria quando ele mesmo poderia passar a compor essa elite econômica. Mas se os recursos são limitados e os desejos não o são, todos poderão gozar infinitamente? É óbvio que não, pelo menos fora da barbárie.

Eis que numa sociedade de exaustos, medicalizados, ansiosos e deprimidos incapazes de manter altos padrões de sucesso e de autoexigência, aparece um vírus - o Coronavírus - invisível ao olho nu, capaz de matar apenas alguns, e embora traga a coroa no nome, afeta a todos independentemente de classes, fronteiras, línguas, discursos ou ideologias, embora prefira idosos e fragilizados - hipertensos, diabéticos, tabagistas. Não há remédio, não há resistência, apenas a quarentena, isolamento, silêncio, paciência.

O confinamento imposto como solução à disseminação do vírus por um lado afeta frontalmente o coração do neoliberalismo, interdita parcialmente as conhecidas formas de consumo, revela que as pessoas e seu bem estar importam para a economia. $\mathrm{O}$ indivíduo a quem foi dito que tudo era possível se vê obrigado a olhar para dentro, a contemplar a si mesmo e a contemplar o sistema que ajudou a construir (BRUM, 2020). E o sistema é compelido a refletir sobre si mesmo (COOPER, 2020). Será que precisávamos mesmo de um novo iPhone? Ou de trinta pares de sapatos? Oferecer saúde universal para todos os cidadãos, em especial aqueles que não podiam pagar pela cobertura privada, é ainda uma má ideia? Harari (2020a) argumenta que não.

O mundo não gira mais veloz e os medos indicados por Freud no século XIX são atualizados e, a partir de uma natureza transformada pelo descuido (BERGER, 2020), se faz circular um inimigo invisível de força incontrolável, desconhecido, uma manifestação de alteridade destruidora do nosso modo de vida, evidenciando a deterioração e decadência do humanos-corpos que, em quarentena e isolamento, são desafiados a confrontar suas construídas formas de 
relação. O nosso modo de vida antes era bom, belo e correto? A pandemia coloca tudo isto em cheque e, segundo Brum (2020) e Cooper (2020), o nosso modo de vida não era bom, belo e nem correto.

O imperativo mandatório do desempenho é deslocado para o espaço virtual, onde só alguns têm acesso e aptidão. Nesse, a hiperinformação, circula revelando-se feita por esses mesmos indivíduos sociais que anseiam poder, controle e consumo, segue, levando com rapidez o vírus do medo, da impotência, do fracasso, da desinformação e da ciência biomédica malfeita ou mal-intencionada (Bauchner $\mathrm{H}$, Golub RM, Zylke, 2020), da impossibilidade de sucesso, da impossibilidade de realizar seus tão antes determinantes projetos.

Entretanto, o vírus se coloca no real do corpo. Colapsa os sistemas de saúde, fecha o comercio, as escolas, a Disney e vários outros avatares do capital neoliberal.

Empresas quebrarão.

Desempregados invadirão as ruas como moradores ou revolucionários.

A fome e a violência crescerão.

Quem será amparado pelo Estado? As pessoas? Os negócios? Quais negócios?

Hoje, confinadas, as grandes potências se igualam aos países subdesenvolvidos, apesar de suas diferenças e privilégios. O dinheiro global se concentra mais ainda, uma elite muito menor se sustenta como pode, a ciência e os discurso baseados no biopoder tentam se refirmar, enfrentam resistência, convolvem, se reestruturam, se desestruturam. Estamos na beira do desconhecido: um precipício ou o sopé de uma montanha?

O Brasil de 2019 agoniza, governantes reafirmaram o terraplanismo, o design inteligente (poderia tranquilamente ser chamado de design ignorante também sem perda epistemológica) e uma certa interpretação moralizante cristã como eixo de um conjunto de políticas neofascistas de exclusão. No Brasil de 2020, o neoliberalismo escancarou sua função de morte em afirmações como: "o país não pode parar, não pode quebrar por causa de 5 mil ou 7 mil mortos" ou "saiam do isolamento, deixem de histeria", " brasileiros podem entrar no esgoto, que não pegam nada".
Com uma força bruta de trabalho precarizada e institucionalmente desprotegida, com uma classe média de trabalhadores que se sentem - ignorantemente patrões, elites; testemunhamos uma pornográfica proposta de morte, sem nenhum pudor.

Mbembe (2018), já apresentava uma leitura histórica sobre esse necropoder, essa necropolítica, sempre presente na história da civilização embaralhando as fronteiras entre homicídio, genocídio e resistência; redenção e sacrifício, martírio e liberdade.

A história do Brasil, marcada pela não ressignificação da escravidão, já há muito, alimenta discursos de morte afirmando a existência de pessoas passíveis de serem exterminados, os pobres, os negros, os LGBT+ etc. Esses sempre estiveram expostos a um desamparo mortal, assim como os velhos. Isso entretanto veio sendo encoberto pelos discursos meritocráticos que são pulverizados pela presença universal de um pequeno vírus. Agora as coisas mudaram, não há nenhum velamento. É plausível que ao fim de 2020 escutemos de algum ministro que a pandemia foi uma benesse, tendo apoiado na sustentabilidade da previdência e revigorado o mercado de trabalho. Gostaríamos de não ler ou escutar isto, mas diante de tantos outros limites morais já transpostos imoralmente neste país, não nos causaria assombro, apenas uma tristeza profunda.

Como reagirão esses sujeitos do desempenho? Alguns também velhos.

Como sustentar-se-á o exercício de exclusão do outro?

Como reagirão esses outros, agora explicitamente afirmados, em rede nacional, como aptos a morrer?

Nós seguimos, atravessados pela vivência da modernidade e simultaneamente da pós-modernidade. Aguardaremos a era do pós-coronavirus nos perguntando sobre quais serão as renúncias necessárias e possíveis para manter a civilização (Harari, 2020b)? Conseguirá o capital abrir mão do controle oligárquico em prol da solidariedade e do coletivo? O capital centralizará ainda mais o poder e a vigilância?

Chegaremos ao fim do ano com um saldo de mortes evitáveis porque não pudemos consumir menos, produzir menos e amar mais, nossas fragilidades subjetivas cooptadas por um estilo de vida kamikaze. 
E consumíamos para esquecermos que não nos conhecíamos e não nos amávamos o suficiente. Esta crise sem precedentes coloca em evidência quem éramos, quem somos e nos questiona: quem queremos ser daqui para a frente?

\section{Referências}

Bauchner, H., Golub RM, \& Zylke J. (2020). Editorial ConcernPossible Reporting of the Same Patients With COVID-19 in Different Reports. JAMA. Recuperado de https:// www.ncbi.nlm.nih.gov/pubmed/32176775. doi:10.1001/ jama.2020.3980

Berger, K. (2020). The Man Who Saw the Pandemic Coming: Will the world now wake up to the global threat of zoonotic diseases? Nautilus. Recuperado de http://nautil.us/ issue/83/intelligence/the-man-who-saw-the-pandemiccoming

Brum, E. (2020). O vírus somos nós (ou uma parte de nós). Recuperado de https://brasil.elpais.com/opiniao/2020-0325/o-virus-somos-nos-ou-uma-parte-de-nos.html

Cooper, R. (2020). The Virus That Tells Us Who We Are. Issues in Science and Technologia. Recuperado de https://issues. org/the-virus-that-tells-us-who-we-are/

Freud, S. (1974a). Reflexões para os tempos de guerra e morte. Edição Standard Brasileira das Obras Psicológicas Completas de Sigmund Freud. Rio de Janeiro: Imago.

Freud, S. (1996). O mal-Estar na civilização (Edição Standard Brasileira das Obras Psicológicas Completas de Sigmund Freud, Vol. 21). Rio de Janeiro: Imago.

Han, B. C. (2017). Sociedade do Cansaço. Petropolis: Vozes.

Han, B. C. (2018). A Expulsão do Outro. Lisboa: Relógio D’agua.

Han, B. C. (2018). Psicopolítica: o neoliberalismo e as novas técnicas de poder. Belo Horizonte: Âyiné.

Harari, Y. N. (2020). In the Battle Against Coronavirus, Humanity Lacks Leadership. Time. Recuperado de https://time. com/5803225/yuval-noah-harari-coronavirus-humanityleadership/

Harari Y. N. (2020). The world after coronavirus. Financial Times. Recuperado de https://www.ft.com/content/19d903086858-11ea-a3c9-1fe6fedcca75

Mbembe, A. (2018) Necropolítica. (3a ed). São Paulo: n-1 edições. 